\title{
A Review of Residential Water Consumption Determinants
}

\author{
Nguyen Bich-Ngoc ${ }^{\bowtie[0000-0002-1299-9363] ~}$ and Jacques Teller ${ }^{\text {[0000-0003-2498-1838] }}$ \\ LEMA, Urban and Environmental Engineering dpt., University of Liège, 4000 Liège, Belgium \\ BichNgoc. Nguyen@uliege.be \\ Jacques. Tellerduliege.be
}

The final publication is available at Springer via https://doi.org/10.1007/978-3-319-95174-4_52

\begin{abstract}
Water supply sectors are facing higher uncertainty in both resource availability and consumer demand. Future conservation programs require a full understanding of underlying factors of residential water consumption. However, previous studies have only considered one or several groups of factors without putting them all together in a bigger picture. This study was developed to provide a comprehensive view on these determinants and their relationships, as well as to discuss current gaps and possible directions. Determinants are categorized into six groups: (1) Economic; (2) Socio-demographic; (3) Physical properties; (4) Technological; (5) Climatic; and (6) Spatial drivers. All these determinants produce a very complex picture with many possible interrelationships. This nature, in one hand, poses challenges in selecting suitable technique to avoid autocorrelation, but on the other hand, provides chances to substitute unavailable important data with proxy variables. We have emphasized the lack of regional and cultural diversity in current studies, as most of them were carried out in developed and arid areas. Hence, a wider range of country specific and local-based studies is needed to better reflect the determinants and their relationships in diverse contexts. In future studies, a broader assessment scope taking into account effects such as feedback loop, spillover, and rebound should also be considered. In addition, these studies must deal with modern issues such as balancing between smart monitoring device utilization and consumer privacy.
\end{abstract}

Keywords: Residential Water Consumption, Determinant, Review, End-use, Smart meter.

\section{Introduction}

Water supply sectors are facing higher uncertainty in both resource availability and consumer demand. Climate change patterns including higher temperatures and alterations in precipitation patterns are likely to impact the inflow to drinking water reservoirs and to cause higher uncertainty in water availability [1]. On the other hand, both increase and decrease in water demand, especially in urban area, have been observed around the world [2-5]. Ongoing population growth, urbanization, and higher living 
standards are among the common identified drivers behind the upsurge in water consumption $[2,6,7]$, while, technology development and mandatory water restrictions are considered the reasons behind the reduction in water use [4]. These uncertain fluctuations in water demand create difficulties for many cities around the world to provide a safe, steady, and affordable drinking water supply [1]. Hence, a full understanding of underlying factors of residential water consumption is vital for the development of a more sustainable water management system.

Determinants of household water consumption has been studied since the late 1960s at different aggregation levels (city, municipal, census tract, household) [8]. At the beginning, price and other socio-economic factors were the dominant focus [8-12]. Besides, physical characteristics of properties such as lot size, size of outdoor space, housing typology, etc. were also often found in water demand modelling literature [13-15]. Technological development including (1) implementation of high water efficiency fixtures and appliance [16-19], (2) providing real-time feedback using smart technology [20] is constantly gaining the interest of water conservation researchers. Climatic effect is also an important factor in water demand modelling, especially when significant amount of water was used externally [21-23]. Not until the beginning of $21^{\text {st }}$ century, spatial dimension started to be considered in water demand literature $[6,8,15]$.

Even though there have been many publications on determinants of water consumption. Previous studies have only considered one or several groups of factors without putting them all together in a bigger picture. This study was developed to provide a comprehensive view on determinants of residential water consumption and their interrelationships. We also discuss the gaps in current literature and possible directions for future research.

\section{Economic Determinants}

Price was one of the first and most studied factors in the water demand management literature [7, 9-12, 24]. Interest in pricing and other economic instruments was backed up by the logic that higher water prices lead to lower consumption. However, that is only true if water behaves as a normal economic goods. Savenije (2002) argued that since most water uses are essential and irreplaceable, market theory could not be simply applied for water demand management [25]. Empirical evidence generally supported that residential water demand is relatively price-inelastic, i.e. large increase in water price generally lead to small or no change in water consumption [10, 11]. However, when zooming in, the price elasticity of water demand varies among different end-uses. Whilst price mechanisms would not make great differences in essential uses, it can significantly affect water-related leisure activities such as gardening or filling swimming pools $[7,26]$. Using water consumption data from Seville (Spain) as a case study, Martínez-Espiñeira and Nauges (2004) discussed the existence of water demand threshold which is the essential amount of water for basic need. When the threshold is approached, increment in price would barely affect demand [27]. Additionally, the impact of price on water consumption also differ among socio-demographic groups. Inman and Jeffrey (2006) hypothesized that water use in low income families was just for basic 
need and could not be reduced even with higher water price [17]. On the other hand, other studies suggested very little or no effect of price on well-off individuals [26] since price signal is not strong enough to curb their consumption [7]. Renwick and Green (2000) also observed that water consumption is more responsive to price change during summertime [28]. These understandings are critical for setting price schemes which can target savings in high consumption group whilst not posing the conservation burden on indispensable uses.

Different water pricing structures were also proven to influence domestic water consumption [9, 12, 29-31]. There has been evidence for effect of increasing block tariffs (IBT) on water demand control [17, 31]. Though IBT is gaining popularity worldwide [32], there are several drawbacks of this pricing scheme. Firstly, it increases revenue instability which in turn leads to affordability problems for the utility companies [26]. A fixed fee independent of the water consumed was suggested to overcome this problem [7, 33]. Secondly, IBT might also fail to promote social equity. Since household with more members are expected to consume more water, they will more likely to be charged higher prices. Moreover, such household often include more vulnerable members such as children and the elderly [34]. In 2003, Liu et al. proposed an increasing block price scheme based on per capita consumption instead of per connection. This scheme is proven to meet both equity and efficiency [30]. Martins et al. (2013) demonstrated that, by introducing social subsidies, the burden of water conservation can be alleviated from large family [34].

\section{Socio-demographic Determinants}

Beside price, other socio-demographic determinants often included in literature are household size [11, 16, 35, 36], income [37-39], age structure [11, 16, 39, 40], education, and immigration $[11,41,42]$.

Whilst studies using aggregate data included average household size as independent variable for water consumption estimation $[15,36]$, household-based studies often considered the number of adults, number of teenagers, and/or number of children in their analyses [16, 30, 43]. Bigger households tend to consume more water in total but less per person [18]. This "economies of scale" effect tends to vanish if the household size is too small [44]. Nevertheless, the Western world has been undergoing a demographic transition [7] with the downsizing of household size and the growth of one-person household [45]. This common phenomenon occurring throughout urban regions of the developed world intensifies the effect of "inefficient" water use in small household [7, 45].

The positive effect of income on water use was widely accepted and empirically demonstrated [7, 37, 38]. Families with higher income tend to have higher total water consumption [39] as well as water consumption per capita [7]. However, Willis et al. observed that the water demand is not significant different between high- and middleincome groups. Low income group shows similar indoor water consumption but much less external water use [18]. 
Though previous studies showed consistent results of income and household size effects on water consumption, there is not an agreement on how age structure influence water use. Using data from South East Queensland (Australia), Bennett et al. (2013) concluded that children generally use less water than adults [16]. Using the same dataset, Beal et al. (2011) also noticed that pensioners tend to use more water than average [40]. Willis et al. argued that retired people tend to spend a relatively great proportion of their time at home, hence, consume more water [46]. Residential water demand data from Aurora, Colorado (US) during a turbulent drought period (2000-2005) also supports positive correlation between average age and water consumption [39]. On the other hand, Nauges and Reynaud (2001) using water expenditure data from Grironde (France) suggested the negative effect of age on water consumption. They argued that older people show more saving attitude and generally use less water [11]. Contradicting results from these studies can be expected since data in Nauges and Reynaud (2001) was collected during the early 1990s while later studies used data from the beginning of $21^{\text {st }}$ century. Culture differences among countries might also have a role in explaining the inconsistent findings.

Even though education level was included in several water consumption studies [8, $16,47]$, others decided to exclude it due to its high correlation with income [48]. Positive influence of education on environmental awareness in general and water conservation attitude in particular was confirmed by Gilg and Barr (2006) [49]. Still, other studies observed the gap between people intention and their actual conservation behavior [50]. In fact, House-Peters et al. (2010) noticed that household with higher percentage of well-educated residents in Hillsboro, Oregon (US) had higher water consumption [41]. Similarly, Makki et al. (2013) found that household group with higher educational level consumes more shower water per person than group with lower educational level [43]. Other studies suggested insignificant effect of education on different water enduses [16].

Other socio-demographic variables such as immigration and religion were not often considered by American and Australian scholars. Using water consumption data in UK, Smith and Ali (2006) made a connection between water use patterns and districts' ethnically and religiously characteristics. The authors argued that since patterns are so tightly related to religious practices, it is expected that religion is also an important factor in water volumes estimation [42]. Nauges and Reynaud (2001) reasoned that immigrants from developing countries often face with water scarcity, hence, they may present more prudent attitudes towards the use of water [11].

\section{$4 \quad$ Physical Property Determinants}

House typology was proven to be significantly connected with water use both indoor and outdoor [13-15]. Fox et al. (2009) classified properties based on number of bedrooms, house type (e.g. flat, terrace, cluster home, or detached), and the presence of garden. Higher water consumption was observed for properties with more bedrooms. However, the authors also noted that the linear relation between property size and number of occupants could not be assumed. This could explain the higher variation in water 
use of properties with five bedrooms and more [14]. House-Peters et al. (2010) also noticed the link between higher water consumption and larger, newer, higher property values [41].

External water use is usually related to leisure activities; thus, it is more susceptible to seasonal and price effects [7]. Presence of swimming pool was identified as the strongest determinant of external use. Families with swimming pool, on average, use twice as much water outdoors as homes without swimming pools [15]. Proportion of properties with swimming pool is positively correlated with average lot size and negatively correlated with urban density [36]. On the other hand, garden irrigation has also been seen as a major component of external water consumption [14]. Beside the size of outdoor space, lifestyle and household attitude toward gardening are significant determinants for outdoor water use [13]. Interestingly, Syme et al. observed that ownership of sophisticated lawn reticulation system do not lead to lower water consumption [13].

Further than being powerful predictors for water demand on their own, characteristics of physical properties can also serve as proxy variables to study the relationship between socio-demographic factors with water demand due to their high correlation. For example, Seyranian et al. (2015) included house size (square feet) and the number of bedrooms as rough proxies for the number of residents in their study [51]. Size, age, and values of properties could also be used as indicators for family income [44].

\section{Technological Determinants}

Applying technology in water conservation has been received much research attention in recent years [19]. Several studies were carried out to assess the effect of water efficient devices on water consumption behavior and water saving $[18,24]$. Recently, technology advancement was also used to give people real-time feedback on the volume and end uses of consumed water [20,32]. This application is expected to raise people awareness and through that inspire water conservation behavior [20].

High efficiency fixtures and appliances were advocated as a low cost solution for sustainable water management [18]. The majority of previous studies suggested that retrofitting high indoor efficiency fixtures could result in a relative savings between 9$12 \%$ [17], whilst comprehensive replacement of household appliance with high water efficiency appliances could reduce indoor water consumption by 35 to $50 \%$ [17]. Reducing water demand also induces positive effect on the whole life cycle cost of drinking water treatment and distribution, and ultimately reduce the ecological footprint of the city or region [18]. Despite the positive results from other studies, Campbell et al. raised concern about offsetting behavior. Their study showed that giving people water saving devices caused very small decreases or fairly large increases in water consumption [24]. Their example of offsetting behavior is when people know that their showerhead is low-flow, they tend to feel free to take longer shower.

Another application of new technology in water conservation is real-time feedback using smart meter, data logger, and in-home displayer [20,32, 52]. Despite the fact that smart meter implementation in water sector is still in its infancy, some positive results were delivered by several studies in Australia. Britton et al. (2013) used smart meter as 
a mean to detect possible post meter leakage [52]. The obtained information was then delivered to targeted household with different communication strategies. Majority of the household fixed the leak which led to $89 \%$ reduction of hour water loss [52]. Instead of leakage, Willis et al. (2010) chose to target shower end-use. The research group provided 151 families in the Gold Coast (Australia) with alarming visual display monitors which were set to alarm after $40 \mathrm{~L}$ of consumed water. The results revealed reductions in both shower duration as well as volume of used water. Also, some participants chose to reduce the flowrate to have longer shower whilst still saving water [20].

On the contrary, a study was conducted in Aurora, Colorado (US) showed that group with water smart reader consumed more water than the control group [32]. It should be noted that Aurora was using the increase block rate system. Hence, when people aware of their real-time consumption, they try to stay in their targeted block to save money but not to save water in general [32].

\section{Climatic Determinants}

The proportion of external water use varies from place to place and can be up to $60 \%$ of total household water consumption during summer time [41]. Whilst indoor use is rather independent of climate, external use is affected by temperature, evaporation, rainfall $[13,22]$. Most studies considered average household water consumption during winter months as base use which generally is not affected by either temperature or rainfall $[22,41]$. The occurrence of rainfall would cause an immediately drop in seasonal use or average water consumption during summer month followed by a gradual increase [23]. Gato et al. (2007) confirmed a non-linear relationship between temperature and water use in the summer using data which was hypothesized in Maidment $e t$ al. study (1985) [22, 23]. Ratio of summer to winter water use varies highly among locations. Balling et al. (2007) reported that the greatest sensitivity to season was found in census tracts with large lots, high occurrence of pools, a large proportion of non-native vegetation, and a high percentage of wealthy residents [21].

Currently, there is an unbalance in water demand literature regarding climatic effect. Majority of the studies were focused on arid and semi-arid climate [39, 41]. Using the case of Oregon (US), House-Peters et al. (2010) reasoned that outdoor use, which is sensitive to variation in climate, also significantly influence residential water consumption in maritime temperate climate [41].

\section{$7 \quad$ Spatial Determinants}

Knowing how people will settle across space is a key to understand the changes in the urban metabolism of water [38]. As said, geography effect on water demand has not been studied until the early 2000s. Most of these studies using aggregate data at municipal or census tract level $[6,4,36]$.

Higher urban density reduces domestic water demand through smaller lot size and outdoor space is the common conclusion from literature $[14,36]$. March and Saurí 
(2010) recognized that net population density, which is expressed as number of residentials per a unit of residential plot area (excluding collector road and commune space), is the most critical variable to explain water consumption [38]. Although high urban density displays a better water efficiency, Hummel and Lux (2007) noticed a trend of lower population density in urban core area due to urban sprawl $[45,53]$. Domene and Saurí (2016) suggested several explanations for this trend including: comparatively cheaper housing in peri-urbanization area, increase the preferences of citizens to be 'closer to nature', and improvements in commuting networks [53].

Moreover, effects of socio-demographic and other factors on water consumption also display spatial variation. Households tend to use water at a level comparable to their neighbors, irrespective of their demographic and economic characteristics [4, 15]. Wentz and Gober (2007) used geographically-weighted regression to model water consumption of Phoenix, Arizona (US) at census tract level. Their model including percent of home with pool, average lot size, percent of residential area of mesic landscaping, and average household size showed vary explanatory power over water use across census tracts. Effects of the average household size and percent of home with pool on water use were proven to be spatial dependent. In other words, an increase in household size of one person increased water use by more than $100,000 \mathrm{~L}$ in some tracts and less than 40,000 L in others [15]. House-Peters et al. advocated the importance of identifying the most water sensitive census blocks and their physical as well as socioeconomic characteristics, as it determines effective targets for conservation efforts [41].

\section{Discussion and Possible Topics for Further Researches}

As noted by Corbella and Pujol (2009), all these determinants produce a very complex picture with many possible interrelationships [7]. Effect of one variable is hardly independent from effect of others. For example, income often positively correlated with age $[16,39]$. Bennett et al. (2013) observed that with age, people move to higher income group and often have more children. However, it could be argued that in other cultural context, the correlation between income and number of children might be very different. Another example could be taken from Millock and Nauges' study in 2010. Their results suggested that socio-economic variables influence people choices of adopting water efficiency equipment [48]. This intercorrelation nature of water demand drivers, in one hand, poses challenges for researchers in choosing suitable modeling technique as well as selecting factors to avoid autocorrelation. On the other hand, when important explanatory variables are not available, proxy variables might be considered to provide the needed information. For instance, building structure variables from tax assessor's record can be used as proxies for income and household size [6].

As discussed in section 6, current knowledge about domestic water demand determinants is rather limited in developed countries, with Australia and US as the two most studied countries [6, 18,33,41]. Several studies has been carried out in Germany [45], France [11], and Spain [36, 53]. With dramatic demographic growth in many urban areas, cities in developing countries are facing challenges to provide adequate services including clean water for their citizen [54]. There is a requirement for specific country 
and location based research [55] because of the differences in: (1) cultural, community norm, religious custom; (2) climate and environmental conditions; (3) technology advancement (at both individual and network level); (4) water pricing structures and legislation, and (5) environmental education.

Traditional researches often considered the effects of explanatory factors on water consumption as one-way. In reality, it is more complicated with possibilities of feedback loop, spillover [45], as well as rebound effects [56]. An example of rebound effect which was discussed in section 5 is when people rely completely on the saving effects of water efficiency fixtures, they tend to change their behaviors in the direction which causing more water consumption [17]. Another complexity of the water demand management is the balancing among environmental, economic, and social sustainability. Whilst observing trend of lower consumption in Meuse basin is positive for natural resource conservation [55], it reduced utility companies' revenue and threatened the companies' ability to maintain the infrastructures. Grafton and Ward (2015) also revealed the welfare losses of mandatory water restriction in Sydney (Australia) [57]. Hence, future studies should consider water demand determinants in a holistic approach with attention to feedback, spillover, and rebound effects.

Empirical results supported that effects of water use predictors change with different end-uses. Whilst household size is important to explain indoor water use, it has almost no effect on external water use [41]. Several studies agreed on the insignificant effect of educational level on total water consumption $[16,48]$. When segregating water consumption for each end-use, education level is a significant determinant for shower/bath and dishwasher end-use categories [16, 58]. Willis et al. (2010) advocated the use of smart meter coupled with data logger for end-use analysis and real-time feedback provision [20]. Even though broadly installation of smart meter could provide researchers with valuable information, concern about individual's privacy has been raised in energy sector [59]. Further investigation should be carried out to find the balancing between consumer privacy and legitimate application of smart meter in water management.

\section{Acknowledgements}

The research was funded through European Regional Development Fund -FEDER (Wal-e-Cities Project)

\section{References}

1. Kristvik, E., Muthanna, T.M., Alfredsen, K.: Assessment of future water availability under climate change, considering scenarios for population growth and ageing infrastructure. J. Water Clim. Chang. jwc2018096 (2018). doi:10.2166/wcc.2018.096

2. $\quad$ Brears, R.C.: Urban water security. John Wiley \& Sons (2017)

3. Fan, L., Gai, L., Tong, Y., Li, R.: Urban water consumption and its influencing factors in China: Evidence from 286 cities. J. Clean. Prod. 166, 124-133 (2017). doi:10.1016/j.jclepro.2017.08.044

4. Franczyk, J., Chang, H.: Spatial analysis of water use in Oregon, USA, 1985-2005. 
Water Resour. Manag. 23, 755-774 (2009). doi:10.1007/s11269-008-9298-9

5. Bartoszczuk, P.: Basics of water pricing and necessity to model municipal water pricing. Proc. Environ. Informatics Ind. Environ. Prot. Concepts, Methods Tools (EnviroInfo 2009), Berlin, Ger. 215-222 (2009)

6. Chang, H., Parandvash, G.H., Shandas, V.: Spatial variations of single-family residential water consumption in Portland, Oregon. Urban Geogr. 31, 953-972 (2010). doi:10.2747/0272-3638.31.7.953

7. Corbella, H.M., Pujol, D.S.: What lies behind domestic water use? A review essay on the drivers of domestic water consumption. Boletín la A.G.E. 50, 297-314 (2009)

8. House-Peters, L.A., Chang, H.: Urban water demand modeling: Review of concepts, methods, and organizing principles. Water Resour. Res. 47, (2011). doi:10.1029/2010WR009624

9. Howe, C.W., Linaweaver, F.P.: The impact of price on residential water demand and its relation to system design and price structure. Water Resour. Res. 3, 13-32 (1967). doi:10.1029/WR003i001p00013

10. Espey, M., Espey, J., Shaw, W.D.D.: Price elasticity of residential demand for water: A meta-analysis. Water Resour. Res. 33, 1369-1374 (1997). doi:10.1029/97WR00571

11. Nauges, C., Reynaud, A.: Estimation de la demande domestique d'eau potable en France. Rev. économique. 52, 167 (2001). doi:10.3917/reco.521.0167

12. Arbués, F., Barberán, R., Villanúa, I.: Price impact on urban residential water demand: A dynamic panel data approach. Water Resour. Res. 40, 1-9 (2004). doi:10.1029/2004WR003092

13. Syme, G.J., Shao, Q., Po, M., Campbell, E.: Predicting and understanding home garden water use. Landsc. Urban Plan. 68, 121-128 (2004). doi:10.1016/j.landurbplan.2003.08.002

14. Fox, C., McIntosh, B.S., Jeffrey, P.: Classifying households for water demand forecasting using physical property characteristics. Land use policy. 26, 558-568 (2009). doi:10.1016/j.landusepol.2008.08.004

15. Wentz, E.A., Gober, P.: Determinants of small-area water consumption for the City of Phoenix, Arizona. Water Resour. Manag. 21, 1849-1863 (2007). doi:10.1007/s11269006-9133-0

16. Bennett, C., Stewart, R.A., Beal, C.D.: ANN-based residential water end-use demand forecasting model. Expert Syst. Appl. 40, 1014-1023 (2013). doi:10.1016/j.eswa.2012.08.012

17. Inman, D., Jeffrey, P.: A review of residential water conservation tool performance and influences on implementation effectiveness. Urban Water J. 3, 127-143 (2006). doi:10.1080/15730620600961288

18. Willis, R.M., Stewart, R.A., Giurco, D.P., Talebpour, M.R., Mousavinejad, A.: End use water consumption in households: Impact of socio-demographic factors and efficient devices. J. Clean. Prod. 60, 107-115 (2013). doi:10.1016/j.jclepro.2011.08.006

19. Carragher, B.J., Stewart, R.A., Beal, C.D.: Quantifying the influence of residential water appliance efficiency on average day diurnal demand patterns at an end use level: A precursor to optimised water service infrastructure planning. Resour. Conserv. Recycl. 62, 81-90 (2012). doi:10.1016/j.resconrec.2012.02.008

20. Willis, R.M., Stewarta, R.A., Panuwatwanich, K., Jones, S., Kyriakides, A.: Alarming 
visual display monitors affecting shower end use water and energy conservation in Australian residential households. Resour. Conserv. Recycl. 54, 1117-1127 (2010). doi:10.1016/j.resconrec.2010.03.004

21. Balling Jr., R.C., Gober, P.: Climate variability and residential water use in the city of Phoenix, Arizona. J. Appl. Meteorol. Climatol. 46, 1130-1137 (2007). doi:10.1175/JAM2518.1

22. Gato, S., Jayasuriya, N., Roberts, P.: Temperature and rainfall thresholds for base use urban water demand modelling. J. Hydrol. 337, 364-376 (2007). doi:10.1016/j.jhydrol.2007.02.014

23. Maidment, D.R., Miaou, S.-P., Crawford, M.M.: Transfer function models of daily urban water use. Water Resour. Res. 21, 425-432 (1985)

24. Campbell, H.E., Johnson, R.M., Larson, E.H.: Prices, devices, people, or rules: The relative effectiveness of policy instruments in water conservation. Rev. Policy Res. 21, 637-662 (2004). doi:10.1111/j.1541-1338.2004.00099.x

25. Savenije, H.H.G.: Why water is not an ordinary economic good, or why the girl is special. Phys. Chem. Earth. 27, 741-744 (2002). doi:10.1016/S1474-7065(02)00060-8

26. Renwick, M.E., Archibald, S.O.: Demand side management policies for residential water use: Who bears the conservation burden? Land Econ. 74, 343-359 (1998). doi: $10.2307 / 3147117$

27. Martínez-Espiñeira, R., Nauges, C.: Is all domestic water consumption sensitive to price control? Appl. Econ. 36, 1697-1703 (2004). doi:10.1080/0003684042000218570

28. Renwick, M.E., Green, R.D.: Do residential water demand side management policies measure up? An analysis of eight California water agencies. J. Environ. Econ. Manage. 40, 37-55 (2000). doi:10.1006/jeem.1999.1102

29. Olmstead, S.M., Michael Hanemann, W., Stavins, R.N.: Water demand under alternative price structures. J. Environ. Econ. Manage. 54, 181-198 (2007). doi:10.1016/j.jeem.2007.03.002

30. Liu, J., Savenije, H.H.G., Xu, J.: Water as an economic good and water tariff design: Comparison between IBT-con and IRT-cap. Phys. Chem. Earth. 28, 209-217 (2003). doi:10.1016/S1474-7065(03)00027-5

31. Olmstead, S.M., Hanemann, W.M., Stavins, R.N.: Does price structure matter? Household water demand under increasing-block and uniform prices. (2003)

32. Strong, A., Goemans, C.: The impact of real-time quantity information on residential water demand. Water Resour. Econ. 10, 1-13 (2015). doi:10.1016/j.wre.2015.02.002

33. Hoffmann, M., Worthington, A., Higgs, H.: Urban water demand with fixed volumetric charging in a large municipality: The case of Brisbane, Australia. Aust. J. Agric. Resour. Econ. 50, 347-359 (2006). doi:10.1111/j.1467-8489.2006.00339.x

34. Martins, R., Cruz, L., Barata, E.: Water price regulation: A review of Portuguese tariff recommendations. Public Organ. Rev. 13, 197-205 (2013). doi:10.1007/s11115-013$0230-2$

35. Gregory, G.D., Leo, M. Di: Repeated behavior and environmental psychology: The role of personal involvement and habit formation in explaining water consumption. J. Appl. Soc. Psychol. 33, 1261-1296 (2003). doi:10.1111/j.1559-1816.2003.tb01949.x

36. Villar-Navascués, R.A., Pérez-Morales, A.: Factors affecting domestic water consumption on the Spanish Mediterranean coastline. Prof. Geogr. 124, 1-13 (2018). 
doi:10.1080/00330124.2017.1416302

37. Dalhuisen, J.M., Florax, R.J.G.M., de Groot, H.L.F., Nijkamp, P.: Price and income elasticities of residential water demand: Why empirical estimates differ. Land Econ. 79, 292-308 (2001). doi:10.2307/3146872

38. March, H., Saurí, D.: The suburbanization of water scarcity in the Barcelona metropolitan region: Sociodemographic and urban changes influencing domestic water consumption. Prof. Geogr. 62, 32-45 (2010). doi:10.1080/00330120903375860

39. Kenney, D.S., Goemans, C., Klein, R., Lowrey, J., Reidy, K.: Residential water demand management: Lessons from Aurora, Colorado. J. Am. Water Resour. Assoc. 44, 192207 (2008). doi:10.1111/j.1752-1688.2007.00147.x

40. Beal, C.D., Stewart, R.A., Huang, T., Rey, E.: SEQ residential end use study. Smart Water Syst. Metering. 80-84 (2011). doi:10.1111/jawr.12036

41. House-Peters, L., Pratt, B., Chang, H.: Effects of urban spatial structure, sociodemographics, and climate on residential water consumption in Hillsboro, Oregon. J. Am. Water Resour. Assoc. 46, 461-472 (2010). doi:10.1111

42. Smith, A., Ali, M.: Understanding the impact of cultural and religious water use. Water Environ. J. 20, 203-209 (2006). doi:10.1111/j.1747-6593.2006.00037.x

43. Makki, A.A., Stewart, R.A., Panuwatwanich, K., Beal, C.: Revealing the determinants of shower water end use consumption: Enabling better targeted urban water conservation strategies. J. Clean. Prod. 60, 129-146 (2013). doi:10.1016/j.jclepro.2011.08.007

44. Arbués, F., García-Valiñas, M.Á., Martínez-Espiñeira, R.: Estimation of residential water demand: A state-of-the-art review. J. Socio. Econ. 32, 81-102 (2003). doi:10.1016/S1053-5357(03)00005-2

45. Hummel, D., Lux, A.: Population decline and infrastructure: The case of the German water supply system. Vienna Yearb. Popul. Res. 167-191 (2007). doi:10.1553/populationyearbook2007s167

46. Willis, R.M., Stewart, R. a, Panuwatwanich, K., Capati, B., Giurco, D.: Gold Coast domestic water end use study. Water J. Aust. Water Assoc. 36, 79-85 (2009)

47. Arbués, F., Villanúa, I.: Potential for pricing policies in water resource management: Estimation of urban residential water demand in Zaragoza, Spain. 43, 2421-2442 (2006)

48. Millock, K., Nauges, C.: Household adoption of water-efficient equipment: The role of socio-economic factors, environmental attitudes and policy. Environ. Resour. Econ. 46, 539-565 (2010). doi:10.1007/s10640-010-9360-y

49. Gilg, A., Barr, S.: Behavioural attitudes towards water saving? Evidence from a study of environmental actions. Ecol. Econ. 57, 400-414 (2006). doi:10.1016/j.ecolecon.2005.04.010

50. Vermeir, I., Verbeke, W.: Sustainable food consumption: Exploring the consumer "attitude - Behavioral intention" gap. J. Agric. Environ. Ethics. 19, 169-194 (2006). doi:10.1007/s10806-005-5485-3

51. Seyranian, V., Sinatra, G.M., Polikoff, M.S.: Comparing communication strategies for reducing residential water consumption. J. Environ. Psychol. 41, 81-90 (2015). doi:10.1016/j.jenvp.2014.11.009

52. Britton, T.C., Stewart, R.A., O'Halloran, K.R.: Smart metering: Enabler for rapid and effective post meter leakage identification and water loss management. J. Clean. Prod. 
54, 166-176 (2013). doi:10.1016/j.jclepro.2013.05.018

53. Domene, E., Saur1, D.: Urbanisation and Water Consumption : Influencing Factors in the Metropolitan Region of Barcelona Urbanisation and Water Consumption: Influencing Factors in the Metropolitan Region of Barcelona. Urban Stud. 43, 16051623 (2006). doi:10.1080/00420980600749969

54. Cohen, B.: Urbanization in developing countries: Current trends, future projections, and key challenges for sustainability. Technol. Soc. 28, 63-80 (2006). doi:10.1016/j.techsoc.2005.10.005

55. Westhoff, M., Dewals, B., Archambeau, P., Dewals, B., Erpicum, S., Pirotton, M.: Towards enhanced estimates of future drinking water demand in the Meuse basin. (2015)

56. Cominola, A., Giuliani, M., Castelletti, A., Rosenberg, D.E., Abdallah, A.M.: Implications of data sampling resolution on water use simulation, end-use disaggregation, and demand management. Environ. Model. Softw. 102, 199-212 (2018). doi:10.1016/j.envsoft.2017.11.022

57. Grafton, Q., Chu, L., Kompas, T., Ward, M.: Understanding and Managing Urban Water in Transition. 15, (2015). doi:10.1007/978-94-017-9801-3

58. Makki, A.A., Stewart, R.A.R.A., Beal, C.D.C.D., Panuwatwanich, K.: Novel bottom-up urban water demand forecasting model: Revealing the determinants, drivers and predictors of residential indoor end-use consumption. Resour. Conserv. Recycl. 95, 1537 (2015). doi:10.1016/j.resconrec.2014.11.009

59. McKenna, E., Richardson, I., Thomson, M.: Smart meter data: Balancing consumer privacy concerns with legitimate applications. Energy Policy. 41, 807-814 (2012). doi:10.1016/j.enpol.2011.11.049 